\title{
DIFH entuaḩa
}

ISSN: 1984-6444 | http://dx.doi.org/10.5902/1984644436730

\section{"Você é viado? Você gosta de homem?": Professores/as homossexuais e o dispositivo de sexualidade na escola}

\author{
"Are you queer? Do you like man?": Homosexuals teachers and sexuality \\ device at school
}

*Filipe Gabriel Ribeiro França

Doutorando em Educação na Universidade Federal de Juiz de Fora - Minas Gerais, Brasil.

filipe.gfranca@yahoo.com.br

Recebido em 02 de fevereiro de 2019

Aprovado em 04 de junho de 2019

Publicado em 07 de agosto de 2019

\section{RESUMO}

Neste texto, são apresentadas narrativas produzidas durante uma pesquisa de mestrado a partir dos encontros com sete professores/as que se auto identificaram como homossexuais. Foi utilizado como referencial teórico-metodológico a perspectiva pós-estruturalista. Por meio dessa perspectiva, puderam ser problematizadas as formas pelas quais os/as professores/as vão se constituindo enquanto docentes homossexuais e discutir como esses/as professores/as vão se produzindo nas relações de poder, nas relações com o outro e, sobretudo, como se relacionam com a instituição escolar. As narrativas obtidas apontam que assumir-se enquanto professor/a homossexual organiza a forma com que o sujeito se comporta dentro escola, vivenciando um contínuo processo de negociação com o outro e consigo mesmo. Além disso, esses/as professores/as vão corajosamente criando suas próprias existências e se distanciando do padrão heteronormativo de ser. Isso é significativo, pois eles e elas rompem com a heteronormatividade, colocam em suspensão as crenças e as lógicas binárias que estão ao nosso redor nos cerceando da experienciação de diferentes modos de vida.

Palavras-chave: Professores/as homossexuais; Constituição docente; Sexualidade.

\section{ABSTRACT}

In this paper, are presented narratives produced during a master's research from the meetings with seven teachers who self identify as gay. Use as a theoretical and methodological framework poststructuralist perspective. Through this perspective could discuss the ways in whichs teachers are constituted as homosexual teachers and discuss how these teachers will be producing power relations, in relations with each other and especially how they relate to the academic institution. The narratives 


\section{A HEM Gutrathá}

ISSN: 1984-6444 | http://dx.doi.org/10.5902/1984644436730

obtained indicate that assuming oneself as a homosexual teacher organizes the way in which the subject behaves in school, experiencing a continuous process of negotiation with the other and with himself. In addition, these teachers will boldly create their own existences and distance themselves from the heteronormative pattern of being. This is significant because they and they break with heteronormativity, suspending the beliefs and binary logics that surround us by curtailing the experience of different ways of life.

Keywords: Homosexuals teachers; Teaching constitution; Sexuality.

\section{Introdução}

Nas próximas páginas dialogo com professores/as que se identificam como homossexuais. Foram convidados para serem coautores/as desta escrita professores/as da educação básica, tendo em vista os poucos estudos existentes que relacionem a sexualidade dos/das professores/as com a profissão docente. Chamo no decorrer deste texto os/as professores/as participantes da pesquisa de coautores/as porque sem as suas narrativas essa escrita não seria possível. A pesquisa não é sobre eles e elas, a pesquisa é com eles e elas! Isso implica que esse trabalho não é produzido apenas por mim, mas sim produzido por uma coletividade de pensamentos, narrativas e modos de existência.

Inspiro-me em Rago (2013) e abro a escrita a tudo aquilo que a prática acadêmica sempre resistiu, sem medo das emoções, das sensibilidades, das subjetividades e mesmo das dúvidas. Construo uma escrita comprometida com a verdade, mas não com a verdade positivista, que vê a linguagem como puro meio de comunicação. A verdade de que trato aqui é aquela à qual Foucault (2010a) se referia ao reviver o conceito antigo de parrhesía, o dizer a verdade sem medo, uma verdade eminentemente política, que fere e provoca. Assim, me constituo como apresentador de outras vidas, apresentador de diferentes vidas.

Os/as docentes coautores/as dessa escrita atuam no ensino fundamental e na educação infantil das redes públicas e privadas do município de Juiz de Fora - MG. A princípio não estabeleci um número fixo de participantes para a pesquisa. Fui trabalhando com os sujeitos que foram apontados pelas redes de sociabilidade dos/das professores/as que aceitaram o convite e se disponibilizaram a participar da 


\section{OF Hsm entinaça}

ISSN: 1984-6444 | http://dx.doi.org/10.5902/1984644436730

pesquisa. As redes de sociabilidade foram sendo criadas pelos/as próprios/as professores/as durante o caminhar da pesquisa. Ainda no início das minhas investigações, um professor tomou conhecimento da minha temática e colocou-se à disposição para participar e contribuir com a minha pesquisa. Esse sujeito foi o disparador das redes de sociabilidade e dos consequentes encontros com os/as outros/as professores/as. Após explicá-lo detalhadamente sobre os objetivos da minha pesquisa e entrevistá-lo, ele me indicou outros/as três professores/as que talvez tivessem interesse em participar da minha investigação. Solicitei que ele realizasse primeiramente o contato e o convite a esses/as professores/as. Só após essa etapa é que eu realizei o contato com os sujeitos que aceitaram o convite. $E$ assim foi se estabelecendo as nossas redes de sociabilidade até chegarmos ao total de sete professores/as coautores/as dessa pesquisa.

Durante esse processo coloquei-me ciente dos percalços que pudessem surgir nessa travessia e aberto às modificações e transformações que se fizeram necessárias, pensando que "o que interessa é o movimento e as mudanças que se dão ao longo do trajeto", pois, "o que importa é o andar e não o chegar" (LOURO, 2008b, p. 13).

$\mathrm{Na}$ tentativa de imergir no campo e buscar informações para serem problematizadas, utilizei como estratégia de pesquisa as entrevistas narrativas, compreendendo que o caminho metodológico

é o de alquimia mesmo, resultando daí uma bricolagem diferenciada, estratégica e subvertedora das misturas homogêneas típicas da modernidade. Alquimia que rompe com as orientações metodológicas formalizadas na e pela academia (particularmente nos cursos de pósgraduação), cuja direção costuma ser a das abordagens classificatórias, [...] em que cada método vem apresentado em estado puro (CORAZZA, 2007, p. 118).

Entendo que a composição metodológica adotada por mim não é nova, já foi inúmeras vezes utilizada. Porém, encarei as entrevistas com os/as professores/as não apenas como um conjunto de falas isoladas, mas como narrativas de si desses/as sujeitos, pois narrar um fato não é apenas relatar ou viver o que já passou, "implica um certo sentido do que somos" (LARROSA, 2002b, p. 68) para os/as professores/as e para mim. 


\section{Fusm entioará}

ISSN: 1984-6444 | http://dx.doi.org/10.5902/1984644436730

Por meio das narrativas, os/as professores/as dão um novo significado ao que já viveram e ao seu presente, fazendo uso das palavras para descrever o que são, quais experiências os marcaram, o que pensam, o que sentem e como vivem. Pensando com Larrosa, quando nos envolvemos com as palavras "damos sentido ao que somos e ao que nos acontece, de como correlacionamos as palavras e as coisas, de como nomeamos o que vemos ou o que sentimos e de como vemos ou sentimos o que nomeamos" (2002a, p. 21).

Nós, seres humanos somos contadores de histórias, sujeitos que, individual e socialmente, vivemos e nos relacionamos com vidas relatadas. Trabalhar com as narrativas é, portanto, estudar as formas como os sujeitos experenciam o mundo. As narrativas e a vida vão caminhando juntas e, portanto, o atrativo principal da narrativa como estratégia metodológica é sua capacidade de conduzir os sujeitos a reproduzirem as suas experiências da vida, de forma relevante e cheia de sentido. Assim como Foucault (2012b, p. 21), "suponho, mas sem ter muita certeza, que não há sociedade onde não existam narrativas maiores que se contam, se repetem e se fazem variar". Narrativas recheadas de "fórmulas, textos, conjuntos ritualizados de discursos que se narram, conforme circunstâncias bem determinadas; coisas ditas uma vez e que se conservam, porque nelas se imagina haver algo como um segredo ou uma riqueza" (idem).

Deste modo, a narrativa constitui-se como uma modalidade discursiva, na qual as histórias que contamos e as histórias que ouvimos, produzidas e mediadas no interior de determinadas práticas sociais, passam a construir a nossa história, a dar sentido a quem somos e a quem são os outros, constituindo assim as nossas identidades - de gênero, sexual, racial, religiosa, de professor/a, de classe social, de mãe e pai, filho/a, entre outras. Assim, construímos e expressamos a nossa subjetividade a partir das formas linguísticas e discursivas que empregamos nas nossas narrativas (RIBEIRO, SOARES e FERNANDES, 2009).

Para chegar até as narrativas dos/das professores/as lancei mão de entrevistas com cada um/a deles/as, acreditando que "as entrevistas não permitem dizer uma ou a verdade sobre as coisas e os fatos, mas pode-se considerá-las como a instância central que, somada a outras, traz informações fundamentais acerca do 


\section{工保W elitua

ISSN: 1984-6444 | http://dx.doi.org/10.5902/1984644436730

vivido e possibilita uma interpretação" (ANDRADE, 2012, p. 175), mesmo que provisória e parcial, das vivências dos/das professores/as homossexuais na escola. Sendo assim, faço a exploração das narrativas, buscando problematizar as construções históricas, sociais e culturais que conduzem a constituição dos discursos e dos sujeitos. Isso implica em

Escapar da fácil interpretação daquilo que está "por trás" dos documentos, procurando explorar ao máximo os materiais, na medida em que eles são uma produção histórica, política; na medida em que as palavras são também construções; na medida em que a linguagem é também constitutiva de práticas (FISCHER, 2001, p. 199).

O que essas narrativas podem produzir? Penso que "pelas narrativas, histórias são escritas e identidades são discursivamente produzidas" (ANDRADE, 2012, p. 180), proporcionando a construção de um texto que se caracterize pelo encontro de múltiplas vozes, de diferentes lugares, contextos sociais e culturais. "As informações que são coletadas em um trabalho de campo não são dados passíveis de serem explicados, mas são significados produzidos no contexto pesquisado, que podem ser lidos e construídos de diferentes formas" (REIS, 2012, p. 247). Essas informações contribuem para o processo de análise discursiva do material coletado nas entrevistas narrativas.

No decorrer desta travessia não pretendi e nem desejei produzir certezas e/ou verdades, pelo contrário, quis que elas fossem problematizadas, colocadas em questão, discutidas, abaladas e desmanchadas.

\section{Professores/as homossexuais e o dispositivo de sexualidade na escola}

Relações de poder, curiosidade e controle. Palavras tão presentes no cotidiano dos/das professores/as homossexuais dentro e também fora do ambiente escolar. As suas sexualidades são colocadas em questão, transformadas em objetos a serem desvendados e ao mesmo tempo controladas. As narrativas desses/as docentes denunciam como eles e elas vão sendo capturados/as pelas relações estratégicas produzidas pelo dispositivo de sexualidade. 


\section{FESH Gitna

ISSN: 1984-6444 | http://dx.doi.org/10.5902/1984644436730

Para compreensão do dispositivo da sexualidade atentarei primeiramente à definição que Foucault faz do termo dispositivo em sua Microfísica do Poder. Ele define o dispositivo como um agrupamento heterogêneo que

engloba discursos, instituições, organizações arquitetônicas, decisões regulamentares, leis, medidas administrativas, enunciados científicos, proposições filosóficas, morais, filantrópicas. [...] O dito e o não dito são os elementos do dispositivo (FOUCAULT, 2012a, p. 364).

Ou seja, o dispositivo é a rede de relações que pode ser estabelecida entre esses elementos, "tem uma função estratégica e está sempre inscrito num jogo de poder e, ao mesmo tempo, sempre ligado aos limites do saber, que derivam desse e, na mesma medida, condicionam-no" (LÓPEZ, 2011, p. 47).

O conceito de dispositivo trazido por Foucault em sua obra pode ser compreendido como um emaranhado de relações que atravessam o indivíduo e a sociedade. Ele comporta linhas de visibilidade, linhas de enunciação, relações de força, processos de (des)subjetivação e de ruptura que se entrelaçam, se misturam, se modificam e também modificam o dispositivo. Este não é estável, é provisório, pois, está em movimento, em transformação.

As relações de poder se manifestam quando estratégias são acopladas ao dispositivo. Essa junção propicia a fabricação de saberes enquanto verdades por meio dos discursos. Podemos observar que "o dispositivo (...) está sempre inscrito em um jogo de poder" (FOUCAULT, 2012a, p. 367), estando ligado a configurações de saber que dele nascem e o condicionam.

Agora ao pensarmos no termo dispositivo aplicado à sexualidade e estrategicamente ligado ao poder, temos segundo nos lembra Foucault (1988), a colocação do sexo em discurso. Mas afinal, de que se trata o dispositivo de sexualidade? Castro (2009, p. 401) destaca que o dispositivo de sexualidade funciona

através de técnicas móveis, polimorfas e conjunturais de poder [...]. Estende incessantemente seu domínio e engendra novas formas de controle [...]. Gira em torno às sensações do corpo, à qualidade dos prazeres, à natureza das impressões [...]. O dispositivo de sexualidade também está ligado à economia, mas através do corpo. 


\section{TFEM Eltua

ISSN: 1984-6444 | http://dx.doi.org/10.5902/1984644436730

Podemos perceber que a sexualidade não pode ser compreendida apenas como prática que envolve o prazer corporal, ela vai além e constitui-se enquanto elemento capaz de subjetivar, classificar e normalizar os indivíduos de acordo com os valores instituídos pela normalização. Ao mesmo tempo, a sexualidade funciona como ponto de ligação estratégico entre o controle exercido sobre os corpos dos indivíduos e a biopolítica da população.

Ao realizar os seus estudos sobre a História da Sexualidade, Foucault nos aponta que o dispositivo de sexualidade "tem, como razão de ser, não o reproduzir, mas o proliferar, inovar, anexar, inventar, penetrar nos corpos de maneira cada vez mais detalhada e controlar as populações de modo cada vez mais global" (FOUCAULT, 1988, p. 118).

A escola participa desses processos. O dispositivo de sexualidade mostra-se presente nessa instituição nas relações estabelecidas e vivenciadas cotidianamente entre os sujeitos que a frequentam. O fundamental no dispositivo de sexualidade é a sua capacidade de penetração e controle do corpo individual e social dos sujeitos (CASTRO, 2009). Esse controle dos corpos é lembrado e narrado pelos/as professores/as nos momentos em que eles e elas tem as suas presenças e sexualidades questionadas por estudantes e por colegas de profissão.

Alguns questionamentos ultrapassam os muros da escola e produzem discursos a partir de encontros ocorridos fora da instituição escolar. Encontrar com estudantes em outros espaços além da escola é algo comum para nós professores/as e com os/as professores/as homossexuais esses encontros também acontecem e a partir deles as suas sexualidades são colocadas em questão. Os professores Medeiro Vaz e Ricardão ${ }^{1}$ narram essas experiências:

\section{Algum estudante já questionou a sua sexualidade?}

Não. Por incrível que pareça não. Os únicos que questionaram foram exalunos meus, que após o ano letivo acabar eu descobri que eles eram gays. Eu nunca cheguei e perguntei se eles eram gays. Eu fui descobrir que eles eram gays quando eu estava na boate e eles falaram: "uai professor, mas você tá aqui". E eu respondi: "mas você também tá aqui?". E não foi um, foram mais de dez alunos. Teve uma sala em que eu fiquei passado porque jamais passou pela minha cabeça que aqueles meninos fossem gays. Eles não davam pinta, falavam de mulher. Acabou o ano e um dia eu estava dentro da boate e aparecem quatro deles dentro dessa boate entre beijos e abraços. E eu pensei: "oh, meus meninos!". Quando a boate funcionava, na 


\section{Fism Ellloará}

ISSN: 1984-6444 | http://dx.doi.org/10.5902/1984644436730

portaria tinha um travesti que foi meu aluno e virou minha aluna. Tem um outro que também era menino, virou travesti também e eu fiquei passado quando eu o vi como travesti. No ano passado eu dei aula pra um travesti (Professor Medeiro Vaz). Fonte: entrevistas realizadas pelo autor.

Já encontrei com aluno que já esbarrou comigo lá na noite, na balada. Por esse fato sabiam e começaram a fazer conversinha dentro da sala de aula e eu cortei e não foi pra frente (Professor Ricardão). Fonte: entrevistas realizadas pelo autor.

No caso narrado pelo professor Medeiro Vaz a surpresa é recíproca entre ele e os estudantes ao se encontrarem em uma boate gay da cidade: "Uai professor, mas você tá aqui". E eu respondi: "mas você também tá aqui?". O diálogo entre professor e estudante demonstra o estranhamento de ambas as partes ao se verem frequentando um ambiente que é marcado, classificado e destinado a homossexuais. Porém, esse lugar também se apresenta como um local de liberdade e realização, onde seus corpos podem expressar suas vontades e desejos sem medos, pudores ou repreensão, bem diferente das regras e controle da instituição escolar. Esses encontros nos fazem pensar que a sexualidade "é tecida na rede de todos os pertencimentos sociais que abraçamos" (LOURO, 2010, p. 31), como nas escolas e também nas "baladas".

As homossexualidades ainda são associadas a estereótipos marcados e difundidos por discursos propagados, sobretudo, pelas mídias. Assim, espera-se que o homossexual masculino seja "pintoso" e "afeminado" e a lésbica seja "masculinizada". Quando os sujeitos não assumem tais características de identificação acabam causando surpresa: "Teve uma sala em que eu fiquei passado porque jamais passou pela minha cabeça que aqueles meninos fossem gays. Eles não davam pinta, falavam de mulher". Esses estudantes se distanciam do "modelo" de homossexualidade masculina, chegando ao ponto de provocar certa confusão na cabeça do professor Medeiro Vaz e são exemplos da multiplicidade de formas possíveis de criação de existências e vivência dos desejos e sexualidades. Assim, não dá para "pensar numa homossexualidade típica e homogênea, existem diferentes formas de sermos homens, mulheres e homossexuais, revelando que se trata sempre de um processo relacional com a presença do "outro"' (FERRARI, 2012, p. 124). 


\section{N

ISSN: 1984-6444 | http://dx.doi.org/10.5902/1984644436730

Corpos e sexualidades são produzidos a todo o momento dentro e fora da escola: "Quando a boate funcionava, na portaria tinha um travesti que foi meu aluno e virou minha aluna. Tem um outro que também era menino, virou travesti também e eu fiquei passado quando eu o vi como travesti. No ano passado eu dei aula pra um travesti". Sujeitos... Sujeitos em construção... Aluno que "virou" aluna, menino que "virou" travesti. Escola de muitos sujeitos, escola de múltiplas sexualidades...

Encontrar com estudantes na "balada" pode provocar repercussões, desdobramentos e "conversinha" dentro da sala de aula. Ser visto na "balada" provoca interpretações por parte dos estudantes e se torna o catalisador de um processo de questionamento da sexualidade do professor Ricardão. Cortar o assunto foi a solução encontrada pelo professor para cessar e conseguir escapar da situação desconfortante instaurada naquele momento.

A desconfiança acerca de suas atuações profissionais também se mostra presente na vida dos/das professores/as coautores/as desta pesquisa. Ser professor/a homossexual na escola gera expectativas sobre como se dará a atuação e a prática pedagógica do/da docente. Nesse sentido, o professor Hermógenes conta a sua experiência ao se tornar diretor da escola, quando todos/as imaginavam que ele seria uma "bicha desvairada":

Houve realmente um choque a partir da questão da sexualidade porque eles achavam que eu ia ser mais uma bicha desvairada do que um profissional e eu tô mostrando a eles que apesar da condição sexual o aspecto profissional tá completamente distanciado. Lógico que todo mundo sabe que eu sou gay, nunca escondi de ninguém, nem dos pais, nem dos alunos, todo mundo sabe, é declarado. Meus namorados sempre vieram aqui e eu apresento eles, não escondo nada, sou um livro aberto, apesar dos namorados me esconderem atrás das páginas desse livro, todos sabem quem é o meu namorado. Nunca escondi, nunca tive essa necessidade e sempre fui muito bem aceito pelos pais. Os pais sempre me ouviram, eu sempre tive essa linguagem aberta com os pais. Até hoje alunos que eu dei aula há 14 anos atrás, os pais me pedem para ir na casa deles conversar com os filhos porque eles só ouvem a mim. Eu sempre acompanhei meus alunos desde a pré-escola até o $5^{\circ}$ ano, porque eu sempre defendi essa proposta do acompanhamento do professor com a mesma turma, porque aí a relação vai ficando estreita e aí temos um período maior para o conhecimento (Professor Hermógenes). Fonte: entrevistas realizadas pelo autor.

De modo geral, salvo raras exceções, em nossa sociedade o/a homossexual admitido/a e desejado/a é aquele/a que disfarça/esconde sua identidade sexual, ou 


\section{THEM entinabal}

ISSN: 1984-6444 | http://dx.doi.org/10.5902/1984644436730

seja, seria "o/a enrustido/a" (LOURO, 2010). Esse modelo de homossexualidade está distante do professor Hermógenes, uma vez que a vida dele é "um livro aberto" para toda a comunidade escolar: "Lógico que todo mundo sabe que eu sou gay, nunca escondi ninguém, nem dos pais, nem dos alunos, todo mundo sabe, é declarado". Declarar-se homossexual quase sempre é um ato cercado de tensão. Agora declarar-se na escola, que é um espaço público, local disciplinar, moderno, de educar o outro e um importante lugar de vivência e constituição das identidades, apresenta-se como um desafio ainda maior, pois,

de acordo com a concepção liberal de que a sexualidade é uma questão absolutamente privada, alguns se permitem aceitar "outras" identidades ou práticas sexuais desde que permaneçam no segredo e sejam vividas apenas na intimidade (LOURO, 2010, p. 29).

Talvez sejam essas cobranças vindas da escola que provocam o professor Hermógenes a estabelecer a separação entre sexualidade e profissionalismo: "Apesar da condição sexual o aspecto profissional tá completamente distanciado". A criação dessa separação por parte do professor nos leva a pensar no lugar dado à homossexualidade em nossa sociedade. Por que manter esse distanciamento? A quem ele interessa? Distanciar profissão e sexualidade parece ter sido a estratégia encontrada pelo professor para legitimar seu trabalho na escola e evitar possíveis aborrecimentos decorrentes da exposição de sua identidade sexual.

O que efetivamente incomoda grande parte dos sujeitos é a manifestação aberta e pública daqueles/as que vivenciam sexualidades não heterossexuais. Porém, o professor Hermógenes destaca uma experiência diferente ocorrida na sua escola: "Nunca escondi, nunca tive essa necessidade e sempre fui muito bem aceito pelos pais". Ao optar em não esconder a sua homossexualidade para a comunidade escolar, o professor trava uma luta cotidiana para expressar uma estética, uma ética, um modo de vida que não quer ser visto como "alternativo" ou "estranho", mas que pretende, simplesmente, existir pública e abertamente, como os demais sujeitos (LOURO, 2010):

Na reunião de professores eu sempre coloco: "vocês acham que pelo fato de eu ser viado o negócio aqui é só bagunça?". Sou gay, sou alegre, mas não sou bagunça. [...]

Ninguém nunca chega e pergunta "você é viado? Você gosta de homem?". 


\section{Fism entuabal}

ISSN: 1984-6444 | http://dx.doi.org/10.5902/1984644436730

Já teve um momento sim, porque eu dentro da sala de aula um aluno me interrogou e eu falei "eu sou viado sim, sou gay. Alguém tem alguma coisa com isso? Alguém paga as minhas contas? Eu sou muito mais homem que você cara. Ser homem não é só carregar peru no meio das pernas". E o aluno respondeu "ah, então o senhor é viado mesmo né professor?" e eu falei "sou, eu te incomodo?" e ele "não, tá tranquilo!". Não tem essa constância de curiosidade. Eu acho que já leram o livro todo. Já passaram da fase de descobrirem se o diretor é ou não é aquilo. Lógico que eu não chego na frente dos pais e falo "olha, eu sou viado!". Não precisa disso, pra quem sabe ler um pingo é letra (Professor Hermógenes). Fonte: entrevistas realizadas pelo autor.

Entre seus/as colegas professores/as, o professor Hermógenes sente a necessidade de enfatizar que ser "gay" e "alegre" não interfere na qualidade e no desenvolvimento de seu trabalho na escola. Ele aponta que não existe um momento específico para que a sua sexualidade seja questionada, porém quando essa situação se concretiza ele não hesita em responder e afirmar que é sim homossexual, destacando que o fato de "ser homem" vai além do aspecto anatômico-biológico. "Me queimassem em fogo, eu dava muitas labaredas muito altas!" (ROSA, 2001, p. 420).

Deste modo, "a diferença sexual [...] não é, nunca, simplesmente, uma função de diferenças materiais que não sejam, de alguma forma, simultaneamente marcadas e formadas por práticas discursivas" (BUTLER, 2010, p. 153). Assim, um professor que, entre tantas características é gay, corre o risco de ser visto e reconhecido, antes de tudo (ou quem sabe somente) como o "professor gay", e quem sabe por isso, ser considerado menos professor. Seffner (2006, p. 87) nos lembra que é a partir da identidade sexual que todas as demais "construções identitárias do sujeito se ordenam, em outras palavras, esta dimensão da sua vida torna-se totalizadora de sua identidade, e quando dele se fala, é para lembrar, em primeiro lugar, sua identidade sexual". Ser homossexual parece vir à frente de todas as outras identidades do sujeito, inclusive à frente da identidade docente.

Ser professor homossexual na escola coloca em evidência a presença da diferença e da multiplicidade sexual no espaço escolar, proporcionando que os/as próprios/as professores/as identifiquem a importância, as marcas e as particularidades de suas presenças nesse ambiente: 


\section{N

ISSN: 1984-6444 | http://dx.doi.org/10.5902/1984644436730

Você identifica alguma diferença em ser professor homossexual na escola em relação aos outros professores?

Eu diria que a diferença não está em ser gay, mas na forma de pensar e de ser. Desde antes de eu ser diretor, tinham alguns casos que os professores me procuravam para resolver para eles. Tipo o menino que se masturbou no banheiro e sujou o banheiro e ninguém tinha o jeito de conversar e eu fui conversar com esse menino para eles e fui tranquilamente. Quando pintavam alguns problemas assim na escola me pediam ajuda para conversar. Mais pra frente eu entrei no grupo do PEAS e a gente começa a falar mais diretamente daquelas coisas, das questões de gênero e sexualidade e aí que a gente vira mesmo referência pra tudo. Outro dia em um problema de violência na escola me pediram para voltar com umas dinâmicas. A gente vira o salvador. Eu te digo hoje com tranquilidade que 0 fato de ser gay na escola cria um ambiente mais positivo do que negativo para o professor, no meu caso pelo menos. Pra mim cria um certo sentido de a gente ser importante por ser gay, por ser diferente. E para a escola a gente fica importante também porque a gente acaba entrando em outros assuntos. Acho que nós gays na escola temos um papel muito interessante (Professor Joca Ramiro). Fonte: entrevistas realizadas pelo autor.

Para o professor Joca Ramiro a sua maior diferença em relação aos/às seus/as colegas professores/as não está no fato de ser homossexual, mas na forma de "pensar e ser" na escola. A ele é atribuída uma diferença que "é nomeada a partir de um determinado lugar que se coloca como referência” (LOURO, 2008a, p. 47). Essa diferença faz com que os/as outros/as professores/as criem uma associação entre o professor Joca Ramiro e os assuntos diretamente relacionados às questões de gênero e sexualidades, sobretudo, devido a sua participação em um programa de educação afetivo-sexual, fazendo com que ele se torne o responsável por essas discussões em sua escola: "Aí que a gente vira mesmo referência pra tudo. [...] $A$ gente vira o salvador". Dessa forma, a diferença deixa de ser alheia e exterior ao sujeito, passando a ser compreendida como parte de sua existência. A diferença deixa de estar ausente para estar presente.

O professor dá um lugar para a sua homossexualidade dentro do ambiente escolar, em que o fato de ser gay é visto como positivo, associando à ideia de que se é "importante por ser gay, por ser diferente". Assim, haveria um benefício do ato de revelar-se homossexual na escola. Miskolci (2012, p. 49) fala que "as diferenças têm o potencial de modificar hierarquias, colocar em diálogo os subalternizados com o hegemônico, de forma, quiçá, a mudar a ordem hegemônica, a mudar a nós mesmos". 


\title{
THEM edtothăa
}

ISSN: 1984-6444 | http://dx.doi.org/10.5902/1984644436730

Tal como o professor Joca Ramiro, o professor Medeiro Vaz traz em sua narrativa a relação existente entre ele e os/as demais professores/as, abrindo a possibilidade para problematizarmos a dicotomia normal/anormal:

\begin{abstract}
Você acha que você é tratado de maneira diferente na escola?
Não, nem um pouco. Por incrível que pareça eu sou tratado do mesmo jeito. Eles me tratam como se eu fosse uma pessoa normal. No último colégio que eu dei aula no ano passado todo mundo sabia que eu era gay. Nesse colégio que eu estou dando aula eu não tenho convivência com os professores, existem panelinhas dentro do colégio. As professoras se acham umas melhores que as outras. Já que é assim eu vou fazer o meu trabalho e vou deixar o barco correr (Professor Medeiro Vaz). Fonte: entrevistas realizadas pelo autor.
\end{abstract}

Na narrativa do professor Medeiro Vaz existe uma questão em particular que me despertou a atenção. Ao ser indagado se sentia que era tratado de forma diferente na escola ele acaba respondendo que o tratam como se ele "fosse uma pessoa normal". Mas afinal, o que é uma pessoa normal? Ser professor homossexual coloca o sujeito no lugar da anormalidade? Quem está autorizado a classificar os sujeitos em normais e anormais?

Tais questionamentos me remetem a pensar na dicotomia normal/anormal a partir dos estudos de Michel Foucault sobre "Os anormais" (FOUCAULT, 2010b), que culminaram no curso de 1975 no Collège de France. Este curso apresenta uma construção genealógica do conceito de "anormal", levantado durante o século XIX, que a princípio estava ligado aos saberes jurídico e penal, até ir-se dirigindo para a psiquiatrização das sexualidades e dos desejos no final do século XIX. Foucault se encarrega de apresentar elementos que apontam as diferentes personagens que antecedem o "anormal", os dispositivos utilizados para essa definição e a emergência das técnicas de normalização.

Ao afirmar que os/as outros/as professores/as o tratam como se ele "fosse uma pessoa normal", o professor Medeiro Vaz acaba se colocando como sendo um sujeito fora da norma, um "anormal". "A razão normal de coisa nenhuma não é verdadeira, não maneja. Arreneguei do que é a força - e que a gente não sabe assombros da noite. A minha terra era longe dali, no restante do mundo. O sertão é sem lugar" (ROSA, 2001, p. 444). A norma está implicada na vida do professor e se manifesta no seu discurso. Assim, "a norma não se define absolutamente como uma 


\section{Fism Gutrathá}

ISSN: 1984-6444 | http://dx.doi.org/10.5902/1984644436730

lei natural, mas pelo papel de exigência e de coerção que ela é capaz de exercer em relação aos domínios a que se aplica" (FOUCAULT, 2010b, p. 43) e além disso ela "não tem por função excluir, rejeitar. Ao contrário, ela está sempre ligada a uma técnica positiva de intervenção e de transformação, a uma espécie de poder normativo" (idem). No entanto, ser professor homossexual desafia a heteronormatividade e produz um movimento de resistência frente ao exercício de poder que se acha fundado e legitimado. Nesse sentido, vamos percebendo que as sexualidades e subjetividades vão sendo produzidas, atravessadas por essas normas e saberes que tentam direcionar os sujeitos para os caminhos ditos como "certos", aqueles em que a sexualidade hegemônica desejada é a heterossexualidade. Há um investimento para a manutenção deste padrão sexual, regido, sobretudo, pela heteronormatividade, que "sublinha um conjunto de prescrições que fundamenta processos sociais de regulação e controle", que tem como objetivo maior "formar a todos para a heterossexualidade ou para organizarem suas vidas a partir de seu modelo supostamente coerente, superior e "natural"' (MISKOLCl, 2009, p. 332). Deste modo, "o que está em jogo é, na verdade, a apologia do normal. A anormalidade não passa, pois, do contraponto necessário para a construção do sentido de normalidade" (MARQUES, 2007, p. 44) e a nomeação de sujeitos "normais" e "anormais".

\section{Algumas considerações longe de serem finais...}

Neste texto, a partir das narrativas dos/das professores/as homossexuais é possível pensar na presença da multiplicidade das identidades sexuais dentro da escola, e estabelecer, ao mesmo tempo a articulação dessas identidades com a identidade profissional, ou seja, o "ser professor/a". Assim, grande parte dos/das professores/as afirmam que não existe uma separação entre as identidades, elas estão juntas e articuladas, apontando para produção de identidades docentes homossexuais. No entanto, ser professor homossexual na escola faz com os/as professores/as se organizem dentro do ambiente escolar, como forma de proteção consigo mesmos. Proteção e cuidado contra as nomeações (maricona, viado, 


\section{工 Wus edtothấ}

ISSN: 1984-6444 | http://dx.doi.org/10.5902/1984644436730

sapatão, etc.) advindas da linguagem e contra as manifestações de homofobia e de ódio que criam hierarquias e subalternidades, ainda presentes e constantes na sociedade e que são refletidas também na instituição escolar.

O estranhamento à presença desses sujeitos na escola mostra o quanto a diferença ainda perturba e desestabiliza as pessoas que estão imersas em uma sociedade de controle, em que os muitos modos de ser e de viver tentam ser podados em detrimento de um regime que propõe caminhos únicos, préestabelecidos e comuns a todos/as. Diante de tanto controle e vigilância, assumir-se enquanto professor/a homossexual torna-se um grande desafio, que arranja a forma com que o sujeito se comporta dentro escola, vivenciando um contínuo processo de negociação com o outro e consigo mesmo. Porém, assumir-se homossexual frente aos/às estudantes é um ato político destacado por alguns professores/as, sobretudo, na perspectiva de mostrá-los e mostrá-las que existem muitas possibilidades de viver a sexualidade, mesmo imaginando as possíveis consequências negativas desse ato no ambiente de trabalho.

Enfim, ser professor homossexual desperta dúvida, desconfiança, curiosidade dentre outros sentimentos. Esses/as professores/as vão corajosamente criando suas próprias existências e se distanciando do padrão heteronormativo de ser. Isso é significativo, pois eles e elas rompem com a heteronormatividade, colocam em suspensão as crenças e as lógicas binárias (homem/mulher, normal/anormal, homossexual/heterossexual, etc.) que estão ao nosso redor nos cerceando da experienciação de diferentes modos de vida. Os/as professores/as homossexuais instigam e provocam os outros e a si mesmos/as a repensarem as práticas sociais que dão sentido e regem a sociedade contemporânea, e que estão pautadas em relações de poder e saber. Mais do que lutar contra as manifestações homofóbicas na escola, esses/as professores/as tem em suas mãos a possibilidade de transformar esse local em um espaço de problematização dos processos de produção das desigualdades e das diferenças, pondo a norma em questão e destacando a instabilidade, a fluidez e a precariedade de todas as nossas identidades. 


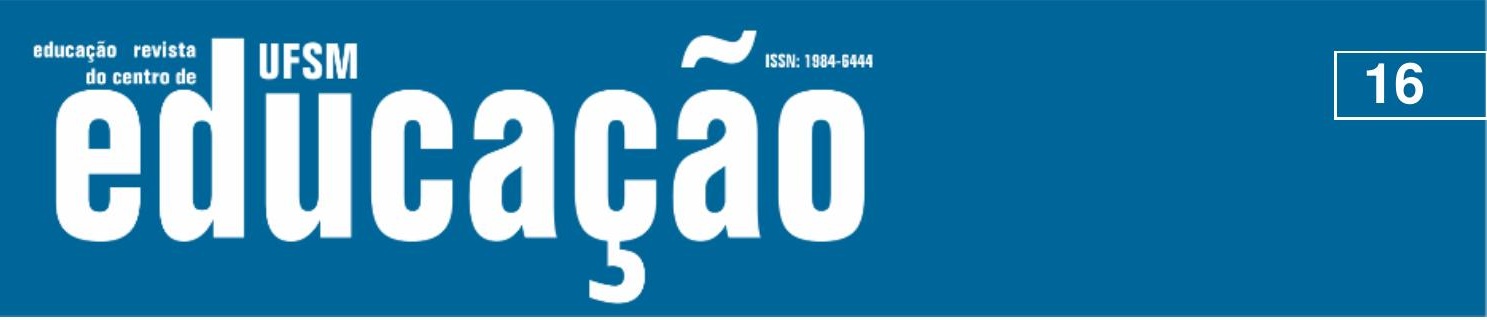

ISSN: 1984-6444 | http://dx.doi.org/10.5902/1984644436730

\section{Referências}

ANDRADE, Sandra dos Santos. A entrevista narrativa ressignificada nas pesquisas educacionais pós-estruturalistas. In: MEYER, Dagmar Estermann; PARAíSO, Marlucy Alves (Organizadoras). Metodologias de pesquisas pós-críticas em educação. Belo Horizonte, Mazza Edições, 2012, p. 173-194.

BUTLER, Judith. Corpos que pesam: sobre os limites discursivos do "sexo". In: LOURO, Guacira Lopes. O corpo educado: pedagogias da sexualidade. $3^{\mathrm{a}}$ ed. Belo Horizonte: Autêntica, 2010, p. 151-172.

CASTRO, Edgardo. Vocabulário de Foucault: um percurso pelos seus temas, conceitos e autores. Belo Horizonte: Autêntica, 2009.

CORAZZA, Sandra Mara. Labirintos da pesquisa, diante dos ferroulhos. In: COSTA, Marisa Vorraber (Organizadora). Caminhos investigativos I: novos olhares na pesquisa em educação. 3ª ed. Rio de Janeiro: Lamparina, 2007, p. 103-127.

FERRARI, Anderson. Sexualidades, masculinidades, orientação sexual. In: XAVIER FILHA, Constantina (Organizadora). Sexualidades, gênero e diferenças na educação das infâncias. Campo Grande, MS: Ed. UFMS, 2012, p. 117-129.

FISCHER, Rosa Maria Bueno. Foucault e a análise do discurso em educação. Cadernos de Pesquisa, № 114, p. 197-223, novembro de 2001. Disponível em: http://www.scielo.br/pdf/cp/n114/a09n114.pdf. Acesso em 10/02/2013.

FOUCAULT, Michel. História da Sexualidade 1: a vontade de saber. Tradução de Maria Thereza da Costa Albuquerque e J. A. Guilhon Albuquerque.19a ed. Rio de Janeiro: Graal, 1988.

FOUCAULT, Michel. A hermenêutica do sujeito: curso dado no Collège de France (1981-1982). Edição estabelecida sob a direção de Francois Ewald e Alessandro Fontana, por Frédéric Gros. Tradução: Márcio Alves da Fonseca e Salma Annus Muchail. $3^{\mathrm{a}}$ Ed. São Paulo: WMF Martins Fontes, 2010a.

FOUCAULT, Michel. Os anormais: curso dado no Collège de France (1974-1975). Tradução: Eduardo Brandão. São Paulo: WMF Martins Fontes, 2010b.

FOUCAULT, Michel. Microfísica do poder. Organização, introdução e revisão técnica de Roberto Machado. 25ª ed. São Paulo: Graal, 2012a.

FOUCAULT, Michel. A ordem do discurso: aula inaugural no Collège de France, pronunciada em 2 de dezembro de 1970. Tradução: Laura Fraga de Almeida Sampaio. 22a ed. São Paulo: Edições Loyola, 2012b.

LARROSA, Jorge. Notas sobre a experiência e o saber de experiência. Revista Brasileira de Educação. 2002a, № 19, p. 20-28. ISSN 1413-2478. Disponível em: http://www.anped.org.br/rbe/rbedigital/RBDE19/RBDE19_04_JORGE_LARROSA_B ONDIA.pdf. Acesso em: 26/07/2012. 
ISSN: 1984-6444 | http://dx.doi.org/10.5902/1984644436730

LARROSA, Jorge. Tecnologias do eu e educação. In: SILVA, Tomaz Tadeu da (Org.). O sujeito da educação: estudos foucaultianos. $5^{\mathrm{a}}$ ed. Petrópolis: Vozes, 2002b, p. 35-86.

LÓPEZ, Maximiliano Valerio. O conceito de experiência em Michel Foucault. Revista Reflexão e Ação, Santa Cruz do Sul, v. 19, n. 2, p. 42-55, jul./dez. 2011. Disponível em: http://online.unisc.br/seer/index.php/reflex/article/view/2367. Acesso em: 11/07/2013.

LOURO, Guacira Lopes. Gênero, sexualidade e educação: uma perspectiva pósestruturalista. 10ª ed. Petrópolis, RJ: Vozes, 2008a.

LOURO, Guacira Lopes. Um corpo estranho - ensaios sobre sexualidade e teoria queer. $1^{\text {a }}$ ed. Belo Horizonte: Autêntica, 2008b.

LOURO, Guacira Lopes. Pedagogias da sexualidade. In: LOURO, Guacira Lopes (Organizadora). 0 corpo educado: pedagogias da sexualidade. $3^{\underline{a}}$ ed. Belo Horizonte: Autêntica, 2010, p. 07-34.

MARQUES, Luciana Pacheco. As diferenças na educação. Revista de Educação do Cogeime. Ano 16, no 30, junho de 2007, p. 43-50. Disponível em: http://www.cogeime.org.br/revista/30Artigo4.pdf. Acesso em: 28/06/2013.

MISKOLCI, Richard. Abjeção e desejo. Afinidades e tensões entre a Teoria Queer e a obra de Michel Foucault. In: RAGO, Margareth; VEIGA-NETO, Alfredo (orgs.). Para uma vida não-fascista. Belo Horizonte: Autêntica, 2009, p. 325-338.

MISKOLCI, Richard. Teoria Queer: um aprendizado pelas diferenças. Belo Horizonte: Autêntica Editora: UFOP, 2012.

RAGO, Margareth. A aventura de contar-se - feminismos, escrita de si e invenções da subjetividade. Campinas: Ed. Unicamp, 2013.

ROSA, João Guimarães. Grande sertão: veredas. 20aㅡ ed. Rio de Janeiro: Nova Fronteira, 2001.

REIS, Cristina d'Ávila. O uso da metodologia queer em pesquisa no campo do currículo. In: MEYER, Dagmar Estermann; PARAísO, Marlucy Alves (Organizadoras). Metodologias de pesquisas pós-críticas em educação. Belo Horizonte, Mazza Edições, 2012, p. 243-260.

RIBEIRO, Paula Regina Costa; SOARES, Guiomar Freitas; FERNANDES, Felipe Bruno Martins. A ambientação de professores e professoras homossexuais no espaço escolar. In: JUNQUEIRA, Rogério Diniz. Diversidade Sexual na Educação: problematizações sobre a homofobia nas escolas. Brasília: Ministério da Educação, Secretaria de Educação Continuada, Alfabetização e Diversidade, UNESCO, 2009, p. 183-211. 


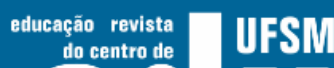

ISSN: 1984-6444 | http://dx.doi.org/10.5902/1984644436730

SEFFNER, Fernando. Cruzamento entre gênero e sexualidade na ótica da construção da(s) identidade(s) e da(s) diferença(s). In: SOARES, Guiomar Freitas; SILVA, Meri Rosane Santos da; RIBEIRO, Paula Regina Costa (Organizadoras). Corpo, gênero e sexualidade: problematizando práticas educativas e culturais. Rio Grande: FURG, 2006, p. 85-94.

\section{Correspondência}

Filipe Gabriel Ribeiro França - Universidade Federal de Juiz de Fora - Campus Universitário, Rua José Lourenço Kelmer, s/n, Bairro São Pedro, CEP 36036-900 Juiz de Fora, Minas Gerais, Brasil.

\section{(c) $\underset{\mathrm{EY}}{(\mathrm{i})}$ (9)}

This work is licensed under a Creative Commons Attribution-NonCommercial 4.0 International (CC BY-NC 4.0)

\section{Notas}

\footnotetext{
${ }^{1}$ Nomes fictícios retirados do romance "Grande sertão: Veredas" de autoria de João Guimarães Rosa
} 